\title{
Hydro-Geoelectric Study of Smoking Hills Golf Resort, Ilara-Mokin Southwestern Nigeria
}

\author{
Adeoye-Oladapo Oluwakemi Olanike
}

\begin{abstract}
Hydro-geoelectric study has been undertaken within the Smoking Hills Golf Resort Ilara-Mokin, Ondo State. The golf resort is situated on the Crystalline Basement Complex rocks of Southwestern Nigeria with the lithology consisting of variably migmatized Biotite-Hornblende-Gneiss with intercalated Amphibolite and Quartzite. The study involved the Direct Current Electrical Resistivity method of geophysical prospecting. The field technique adopted is the vertical electrical sounding (VES) utilizing the Schlumberger configuration. Twenty five (25) VES stations were occupied within the study area. The sounding curve types obtained from the field data are KH, H, HKH, KQ, AK, KQH, AKQ, K and KHK. The sounding data presented a lithologic sequence consisting of the topsoil, thick weathered basement, partially weathered/fractured basement and the fresh bedrock. The overburden materials within the golf resort which are generally in excess thickness of $\mathbf{2 1 . 8} \mathrm{m}$ with maximum thickness of $\mathbf{1 2 0 . 9}$ $m$ constitute the main aquifer units with possibility of fairly adequate yield at twenty one VES locations. A combination of overburden materials and the partially weathered/fractured basement constitute aquifer units with fairly adequate yield at three VES locations while the partially weathered/fractured basement constitutes the main aquifer unit at one VES point. The groundwater potential of Smoking Hills Golf Resort is of low ranking beneath two VES locations (VES 15 and VES 20) and of medium ranking beneath the remaining twenty three (23) VES locations.
\end{abstract}

Index Terms - Smoking Hills Golf Resort, Vertical Electrical Sounding (VES), aquifer, Partially Weathered/Fractured Basement.

\section{INTRODUCTION}

Golf resorts are established for recreational purposes. Towns or communities playing host to golf resorts are centers of attraction for tourism. The local economy is boosted while the golf resorts provide employment opportunities for local hands. Operations of golf resorts require adequate availability of facilities such as water, communication facilities and electricity. While communication and electricity can be provided easily when they are not available, same cannot however be the case for water. Once water is not available in form of surface water, the alternative is to explore for possibility of groundwater abstraction.

A previous hydrogeophysical study of Ilara-Mokin (Oladapo et al., 2009) indicated preponderance of poor to marginal groundwater potential thus implying inadequate potable water accessibility in the absence of pipe borne water supply scheme. However, due to erratic hydrogeologic setting

Adeoye-Oladapo Oluwakemi Olanike, Department of Physics, Adeyemi College of Education, Ondo Nigeria of the basement complex environment, geophysical study has been undertaken within the Smoking Hills Golf Resort area to determine if the underlying poor hydrogeologic setting in Ilara-Mokin extends to the resort located southeast of the town.

Identifying a good site for groundwater development in hard rock terrain is a challenging task (Das et al., 2007). Even though groundwater resources are widely distributed, nature does not provide groundwater at the places of our choice (Badrinarayanan, 2009). Wide and erratic variations of aquifer parameters often characterize the groundwater regime (Mondal et al, 2008) especially within the hard rock environment. Spatial variation of these characteristic parameters attribute to, among other causes, tectonic set-up and degree of weathering of near-surface rocks (Barker et al, 2001). In hard rocks, groundwater occurs in secondary porosity developed due to weathering, fracturing, faulting, etc., which is highly variable within short distance and contributing to near-surface in-homogeneity (Mondal et al, 2008)

The use of geophysical methods provides valuable information with respect to distribution, thickness, and depth of groundwater bearing formations (Ariyo and Adeyemi, 2009). Geophysical method is the application of principles of physics to study the earth by taking measurements at or near the surface of earth (Nazri et al., 2012). The method remains the most suitable tool in exploration for groundwater. Electrical Resistivity Method (ERM) is part of geophysical methods which has been applied for many years to determine the thickness of layered media as well to map geological environment of existing aquifers (Riwayat et al., 2018). It has been effectively used for groundwater due to simplicity of the technique, efficient and non-destructive of implementation and producing subsurface imaging compared to conventional method. Various surface geophysical techniques are available but the most commonly used in Nigeria for rural/urban water supply is the Electrical Resistivity Method because of its low cost and relatively high diagnostic value (Ariyo and Adeyemi, 2009).

\section{LOCATION DESCRIPTION}

Smoking Hills Golf Resort is situated about $1 \mathrm{~km}$ east of Ilara-Mokin town (Figure 1) on the old Ilara-Mokin/Akure roadway. The golf resort has been carefully carved out of 140 acres of surrounding jungle and rolling hills which emit smoke early in the morning, the phenomenon from which the resort drives its name (https://www.hotels.ng). The golf resort is divided into 18 sections like any other standard golf 
resort with individual holes varying in length between $90 \mathrm{~m}$ and $550 \mathrm{~m}$. The starting points of the holes are established at the southern flank of the golf resort since the area slopes generally in the northern direction into a perennial stream. The first tee of the golf resort is located on the southeastern flank while the fairway is located on the northwestern flank. Natural hazards constituting the rough of the golf resort are present on the western (marshy lowland jungle) and eastern (Quartzite ridge) flanks of the area.

\section{GEOLOGY, HYDROGEOLOGY AND GEOMORPHOLOGY}

Smoking Hills Golf Resort is underlain by rocks of the Precambrian Basement Complex of Southwestern Nigeria (Figure 2). The lithologic units include variably migmatized Biotite-Hornblende-Gneiss with intercalated Amphibolites and Quartzites. North-South trending ridge of Quartzite bounds the golf resort on the eastern flank while boulders of Amphibolites/Charnockite rocks are located in the western and northwestern areas of the golf resort.

Basement complex rocks are inherently characterized by low porosity and near negligible permeability; water-bearing voids in them are usually in the form of fissures, fractures, joints and weathered zones. The apparent heterogeneities and complexities present in the basement complex rocks aquifers makes it a challenging research to tackle groundwater problems (Akanbi, 2018; Ahmed et al., 2008).) In basement rock environment, as typified by Ilara-Mokin town, groundwater accumulation depends primarily on the thickness of the overburden, the degree and nature of fracturing/weathering of the bedrock, the presence or absence of clay above the weathered zone, effect of clay on the rate of infiltration of water into the weathered zones and permeability of the weathered/fractured zone.

Thus, the aim of geophysical prospecting for groundwater in basement complex terrain of this nature

is to map structural features - faults, fractures, joints and extended zone of weathering as well as the distribution and thickness of the overburden, all of which invariably control the accumulation of groundwater in such areas.

The Smoking Hills Golf Resort environment is situated on undulating terrain with GPS recorded elevation in the area varying between $367 \mathrm{~m}$ and $424 \mathrm{~m}$ above mean sea level. The region which lies within the tropical rainforest of Nigeria is characterized by two distinct seasons (wet from March to October and dry from November to February). The annual mean rainfall is about $1800 \mathrm{~mm}$. The annual mean temperature ranges between $24^{\circ} \mathrm{C}$ and $27^{\circ} \mathrm{C}$.

\section{MATERIALS AND METHOD OF STUDY}

ABEM SAS 1000 (www.abem.se) resistivity meter complete with peripherals was used for the field data acquisition in form of resistivity measurements. The GARMIN GPS 72 Global Positioning Systems were used to determine co-ordinates and approximate altitude above sea level, while a Compass Clinometer was used to measure Whole Circle Bearing (WCB).

The Direct Current Electrical Resistivity method adopted for the study involved the passage of electric current into the ground through two (2) current electrodes while the potential gradient (voltage) is measured across another pair of electrodes (potential electrodes), which may or may not be within the current electrodes, depending on the configuration. The apparent resistivity of the sub-surface is calculated from the measured resistance. The survey technique adopted for this study is the Vertical Electrical Sounding (VES), using the Schlumberger array.

The field data acquisition which was undertaken in the wet season (June) involved twenty five (25) vertical electrical soundings. The VES stations were distributed across the golf resort as shown in Figure 2. Current electrode separation (AB) ranged from a minimum of 2 metres to a maximum of 200 and $300 \mathrm{~m}$ at eight and seventeen locations respectively. The field data are presented as logarithmic graphs on both axes (Figure 3).

The curves are interpreted qualitatively in terms of the vertical distribution of the calculated formation resistivity using the traditional methods of auxiliary point techniques while quantitative interpretation of the curves involved partial curve matching using two-layer Schlumberger master curves and the auxiliary $\mathrm{K}, \mathrm{Q}, \mathrm{A}$ and $\mathrm{H}$ curves. 


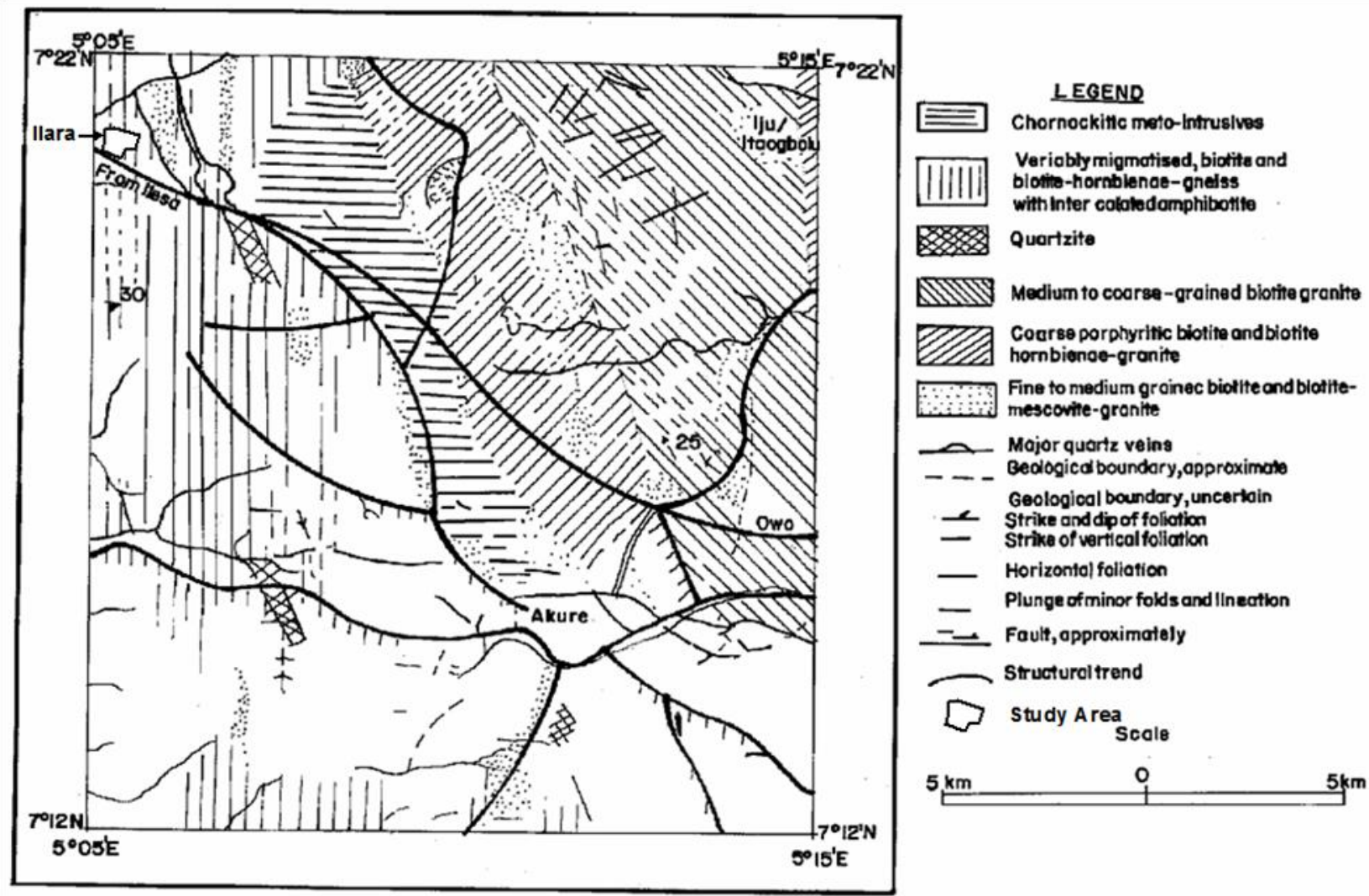

Figure 1: Geological map of the area around Ilara-Mokin

\section{RESULTS AND DISCUSSION}

The field data acquired are presented as sounding curves in the format presented Figure 3 and 1-D geo-electric sections in Figure 4 (a-e). The curve types obtained from the field data are 4 - layer KH (VES 1, VES 6, VES 9, VES 13, VES 14, VES 15, VES 19, VES 21, VES 22, VES 23, VES 24 and VES 25); 3 - layer H (VES 2); 5-layer HKH (VES 3, VES 10 and VES 20); 4 - layer KQ (VES 4 and VES 12); 4 - layer AK (VES 5); 5 - layer KQH (VES 8, VES 11 and VES 16); 5 layer AKQ (VES 17); 3-layer K (VES 18) and 5 - layer KHK (VES 7). The summary of the interpretation results are presented in Table 1.

A summary of the interpretation results of the surface geophysical investigation carried out at Smoking Hills Golf Resort in Ilara-Mokin in terms of geo-electric/geologic layering as classified from the field curves and depicted in Figure 4 is presented as follows:

1st Layer: $\begin{aligned} & \text { Topsoil; } \\ & \text { sand/Laterite }\end{aligned} \quad$ Clay/Sandy Clay/Clayey
Layer resistivity: $8-574 \Omega-\mathrm{m}$

Layer thickness: $0.4-7.7 \mathrm{~m}$

2nd Layer: Laterite Sub-stratum (top of weathered basement)

Layer resistivity: $99-3168 \Omega-\mathrm{m}$

Layer thickness: $0.8-20.0 \mathrm{~m}$

3rd Layer: Weathered Basement

Layer resistivity: $10-249 \Omega-\mathrm{m}$

Layer thickness: $18.1-107.9 \mathrm{~m}$

4th Layer: $\quad$ Partially Weathered/Fractured Basement Layer resistivity: $38-974 \Omega-\mathrm{m}$ Layer thickness: $26.5-35.9 \mathrm{~m}$

\section{5th Layer: $\quad$ Fresh Basement}

Layer resistivity: $351-1272 \Omega-\mathrm{m}$

Depth to Bedrock: $21.8-120.9 \mathrm{~m}$ 
Hydro-Geoelectric Study of Smoking Hills Golf Resort, Ilara-Mokin Southwestern Nigeria

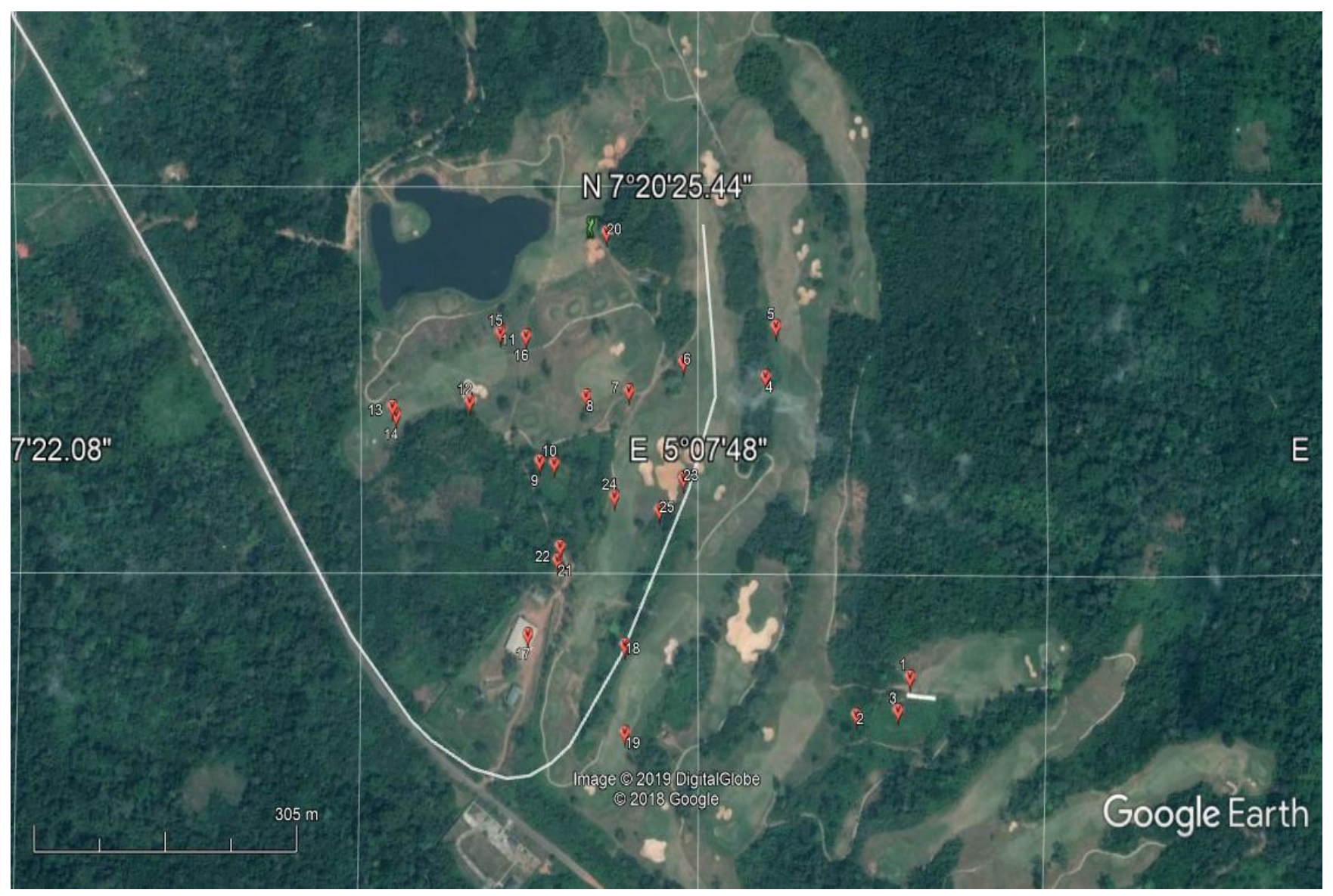

Figure 2: Satellite Image of Smoking Hills Golf Resort showing geophysical data points

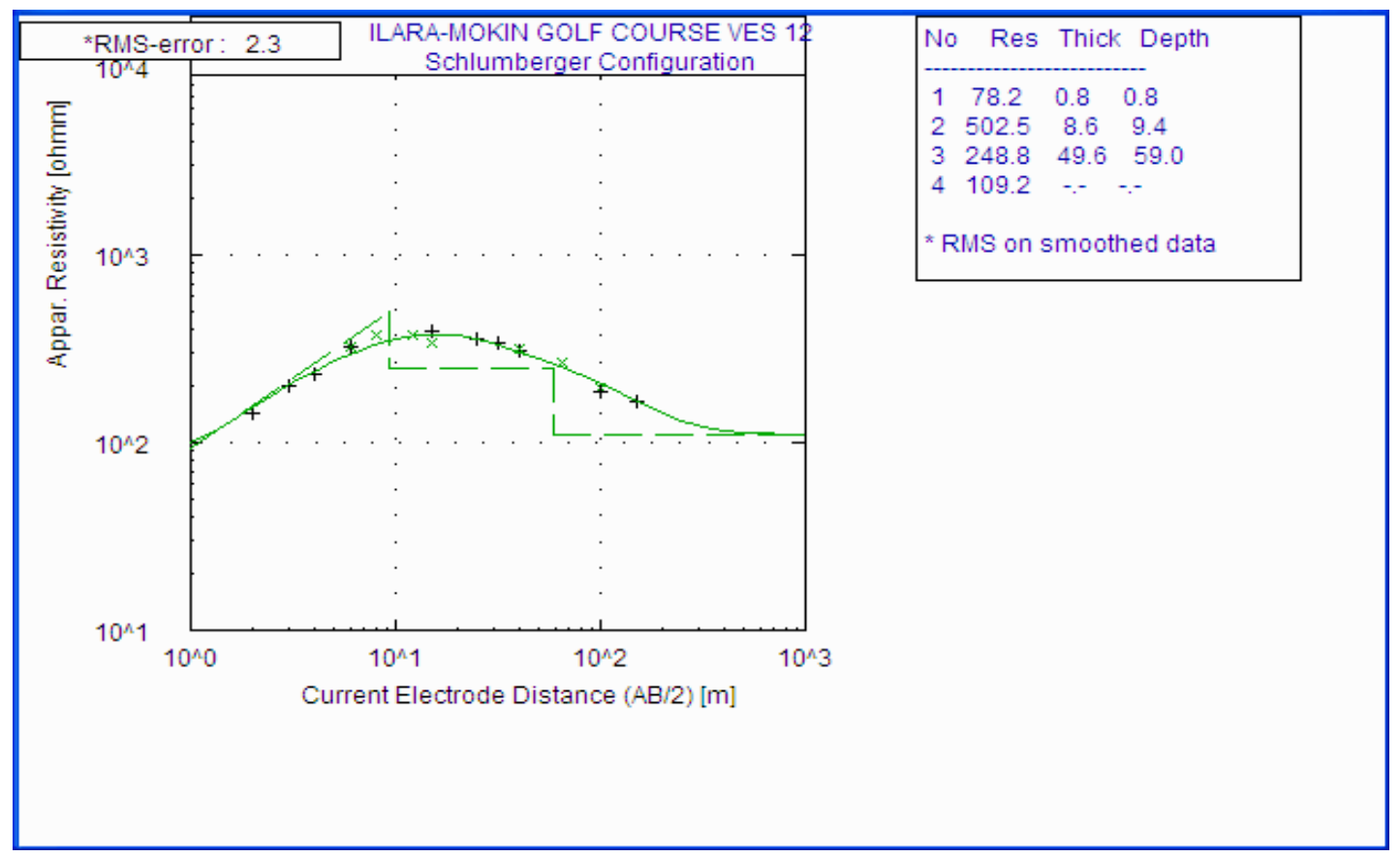




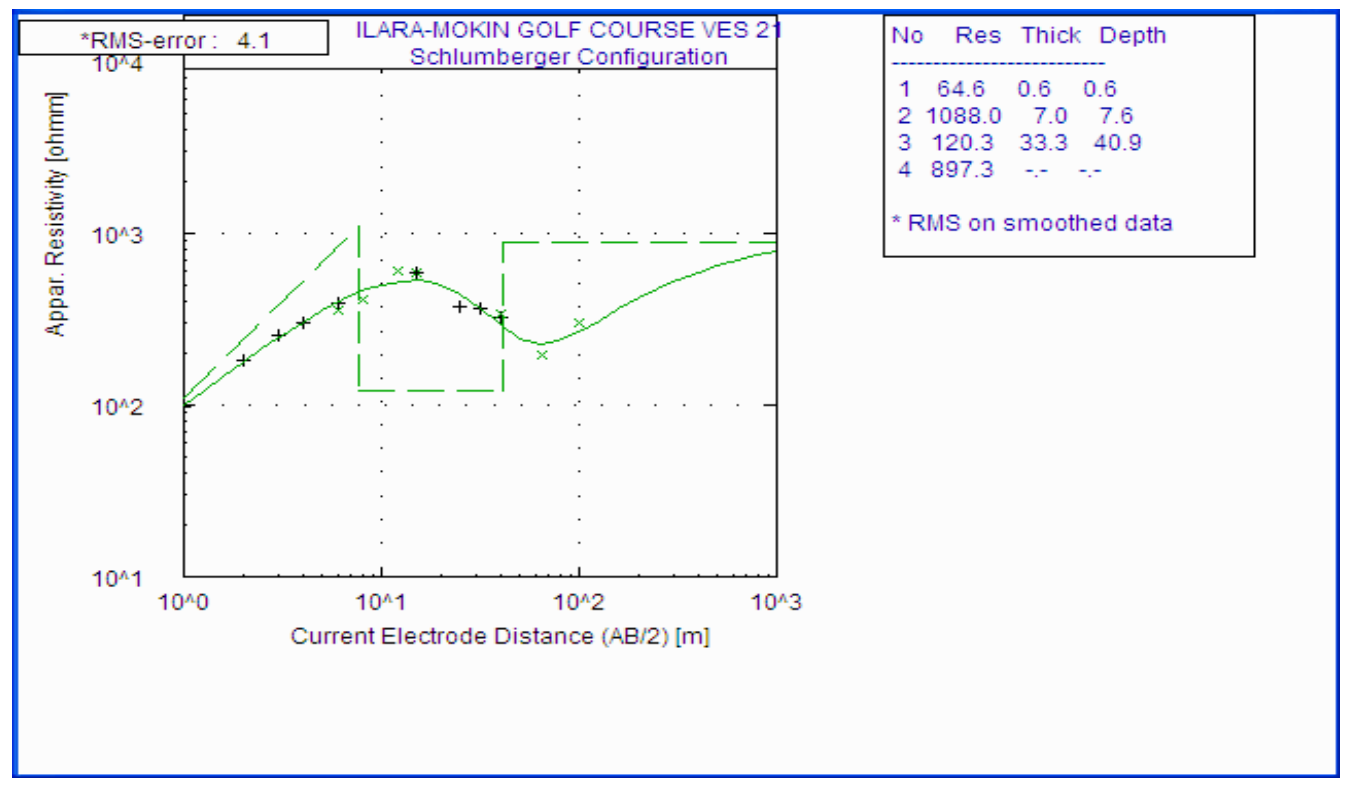

Figure 3: Typical sounding curves obtained from Smoking Hills Golf Resort

Table 1: Summary of Geo-electric Data Interpretation in Smoking Hills Golf Resort

\begin{tabular}{|c|c|c|c|c|}
\hline VES No. & $\begin{array}{c}\text { Depths }(m) \\
d_{1} / d_{2} / \ldots \ldots . . . / d_{n-1}\end{array}$ & $\begin{array}{c}\text { Resistivity }(\Omega-m) \\
\rho_{1} / \rho_{2} / \ldots \ldots \ldots / \rho_{n}\end{array}$ & $\begin{array}{c}\text { Curve } \\
\text { Type }\end{array}$ & (Groundwater Potential Rating) \\
\hline 1 & $1.5 / 15.5 / 49.9$ & $223 / 404 / 120 / 482$ & $\mathrm{KH}$ & Medium \\
\hline 2 & $7.7 / 52.8$ & $190 / 59 / 231$ & $\mathrm{H}$ & Medium \\
\hline 3 & $0.5 / 1.2 / 6.6 / 28.6$ & $343 / 117 / 1447 / 94 / 168$ & $\mathrm{HKH}$ & Medium \\
\hline 4 & $1.8 / 10.0 / 28.2$ & $279 / 3168 / 678 / 479$ & KQ & Medium \\
\hline 5 & $0.8 / 5.7 / 41.6$ & 238/361/974/140 & AK & Medium \\
\hline 6 & $1.1 / 9.8 / 62.1$ & $72 / 902 / 83 / 815$ & $\mathrm{KH}$ & Medium \\
\hline 7 & $1.0 / 8.7 / 52.1 / 78.6$ & $85 / 313 / 89 / 137 / 38$ & KHK & Medium \\
\hline 8 & $0.7 / 4.5 / 16.3 / 47.9$ & $95 / 510 / 230 / 49 / 891$ & $\mathrm{KQH}$ & Medium \\
\hline 9 & $0.7 / 20.7 / 74.6$ & $171 / 760 / 154 / 593$ & $\mathrm{KH}$ & Medium \\
\hline 10 & $0.8 / 8.1 / 18.1 / 59.6$ & $574 / 527 / 1267 / 112 / 1268$ & $\mathrm{HKH}$ & Medium \\
\hline 11 & $0.9 / 13.9 / 28.7 / 67.2$ & $105 / 384 / 174 / 55 / 1272$ & $\mathrm{KQH}$ & Medium \\
\hline 12 & $0.8 / 9.4 / 59.0$ & 78/503/249/109 & KQ & Medium \\
\hline 13 & $0.6 / 4.7 / 55.1$ & $132 / 753 / 145 / 245$ & $\mathrm{KH}$ & Medium \\
\hline 14 & $2.6 / 5.9 / 73.8$ & $397 / 817 / 127 / 277$ & KH & Medium \\
\hline 15 & $0.4 / 3.7 / 21.8$ & $8 / 443 / 10 / 584$ & $\mathrm{KH}$ & Low \\
\hline 16 & $0.7 / 5.2 / 14.5 / 42.6$ & 209/583/524/70/890 & $\mathrm{KQH}$ & Medium \\
\hline 17 & $0.8 / 2.6 / 6.1 / 35.9$ & $109 / 218 / 537 / 217 / 59$ & $\mathrm{AKQ}$ & Medium \\
\hline 18 & $3.3 / 9.6$ & $404 / 1496 / 68$ & $\mathrm{~K}$ & Medium \\
\hline 19 & $0.7 / 16.1 / 120.9$ & $127 / 342 / 96 / 454$ & KH & Medium \\
\hline 20 & $0.7 / 1.7 / 7.0 / 37.0$ & 225/99/741/20/908 & $\mathrm{HKH}$ & Low \\
\hline 21 & $0.6 / 7.6 / 40.9$ & 65/1088/120/897 & KH & Medium \\
\hline 22 & $1.6 / 14.9 / 76.3$ & $156 / 669 / 107 / 447$ & KH & Medium \\
\hline 23 & $0.6 / 10.2 / 118.1$ & $104 / 515 / 157 / 450$ & $\mathrm{KH}$ & Medium \\
\hline 24 & $0.7 / 8.0 / 73.7$ & $102 / 474 / 99 / 351$ & $\mathrm{KH}$ & Medium \\
\hline 25 & $1.0 / 13.3 / 69.6$ & 70/318/101/958 & $\mathrm{KH}$ & Medium \\
\hline
\end{tabular}


Hydro-Geoelectric Study of Smoking Hills Golf Resort, Ilara-Mokin Southwestern Nigeria

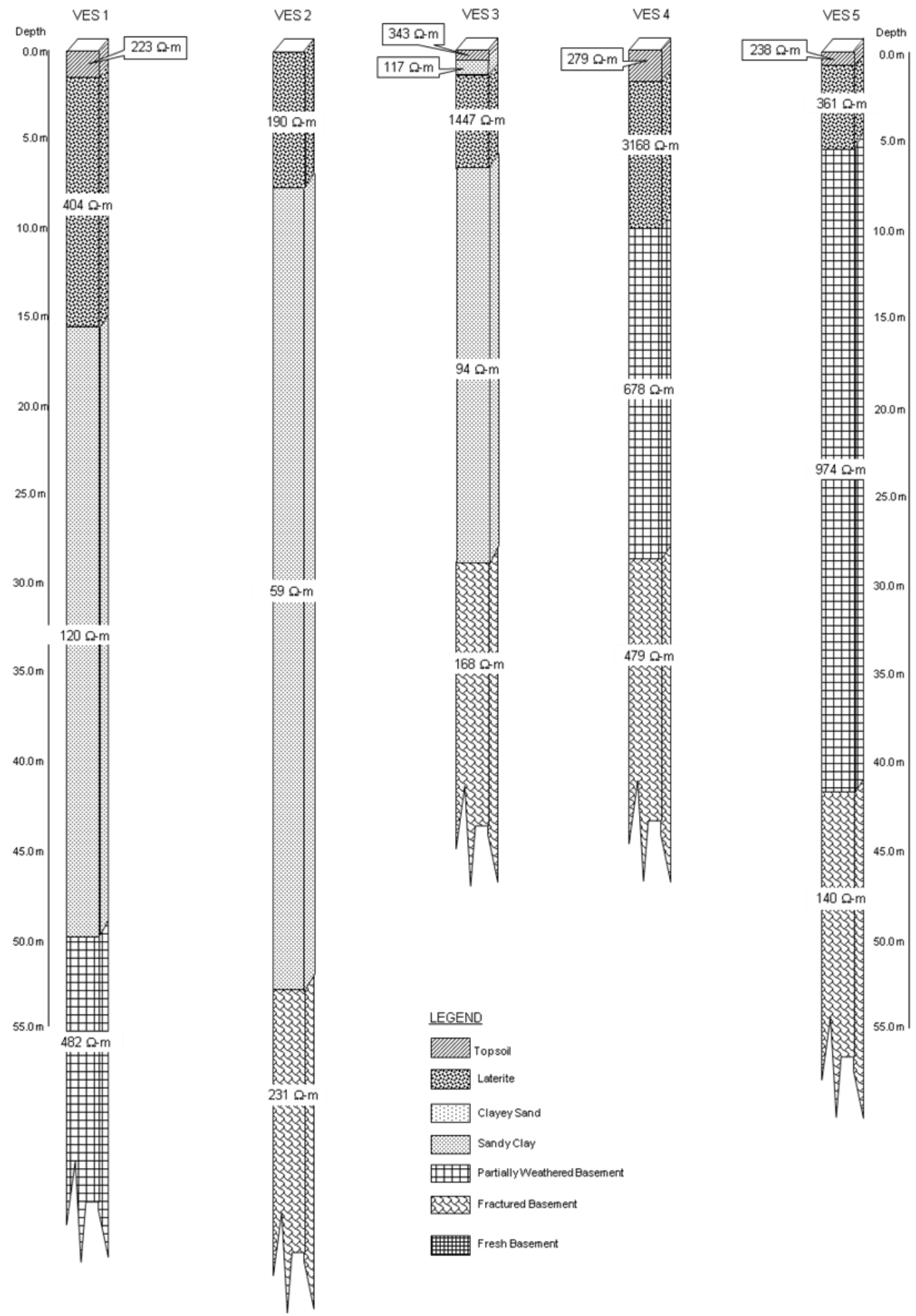

Figure 4a: 1-D Geoelectric sections of VES 1 VES 2, VES 3, VES 4 and VES 5 (Smoking Hills Golf Resort, Ilara-Mokin) 
World Journal of Innovative Research (WJIR) ISSN: 2454-8236, Volume-6, Issue-4, April 2019 Pages 71-81
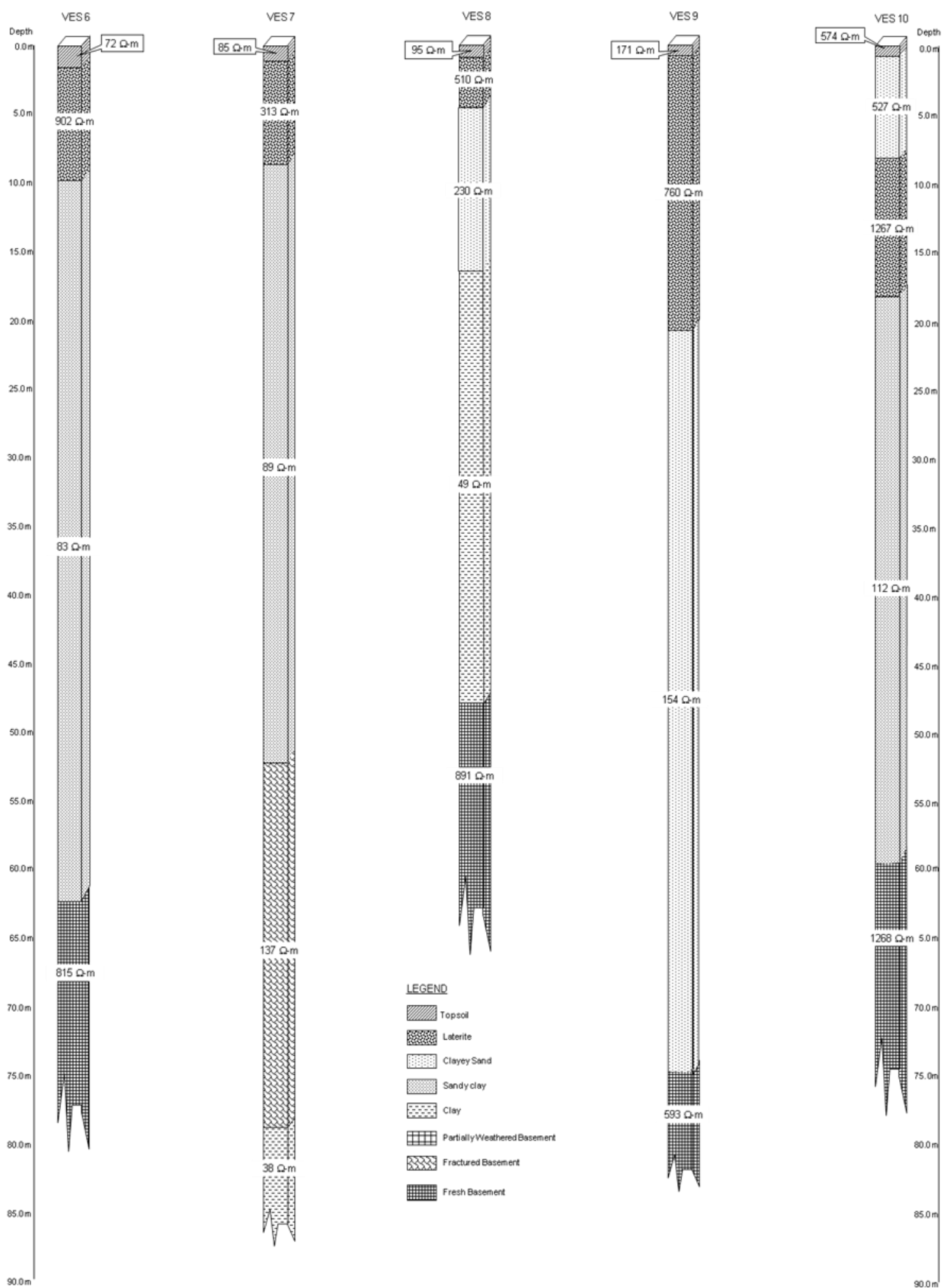

Figure 4b: 1-D Geoelectric sections of VES 6 VES 7, VES 8, VES 9 and VES 10 (Smoking Hills Golf Resort, Ilara-Mokin) 
Hydro-Geoelectric Study of Smoking Hills Golf Resort, Ilara-Mokin Southwestern Nigeria
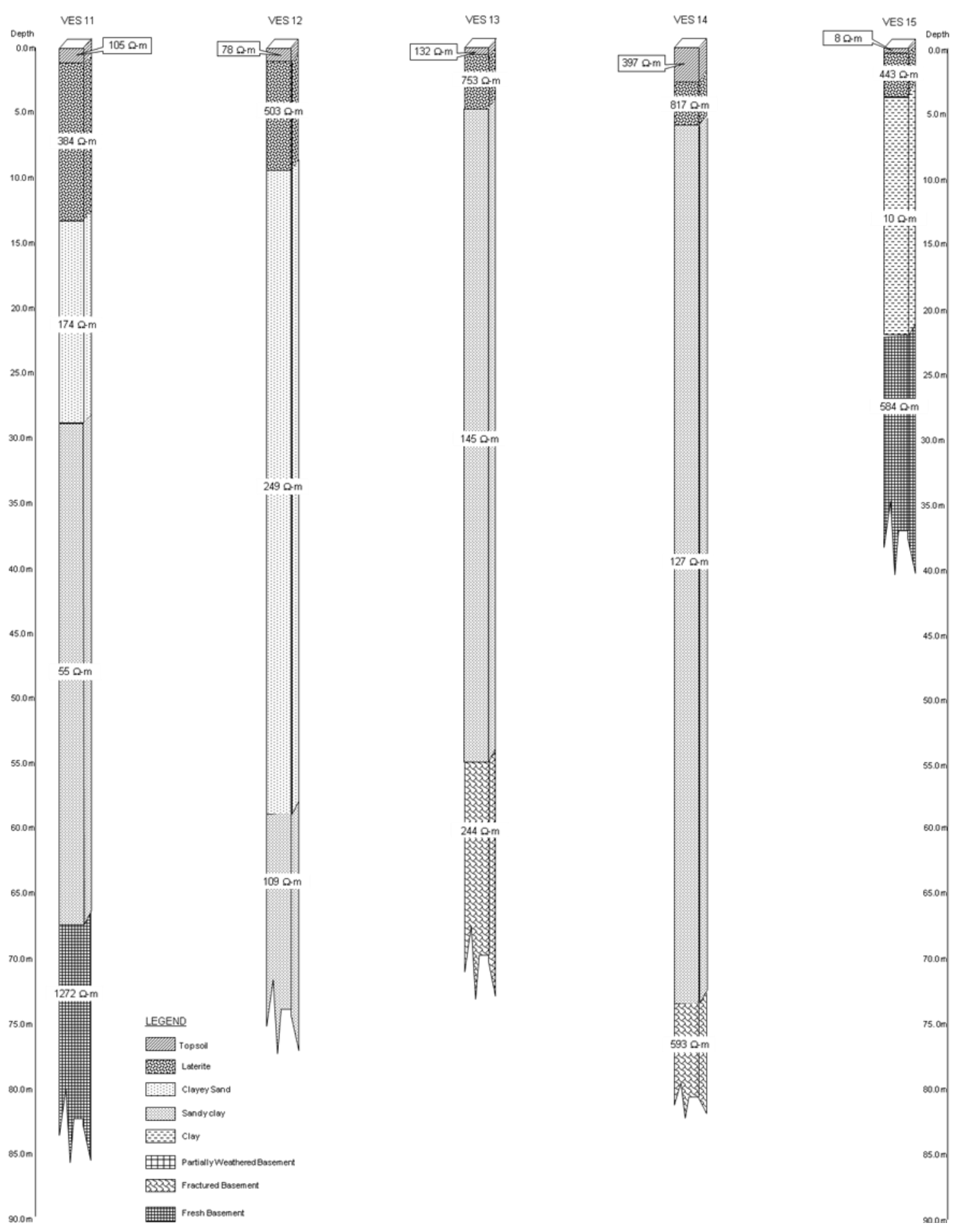

Figure 4c: 1-D Geoelectric sections of VES 11 VES 12, VES 13, VES 14 and VES 15 (Smoking Hills Golf Resort, Ilara-Mokin) 
World Journal of Innovative Research (WJIR) ISSN: 2454-8236, Volume-6, Issue-4, April 2019 Pages 71-81
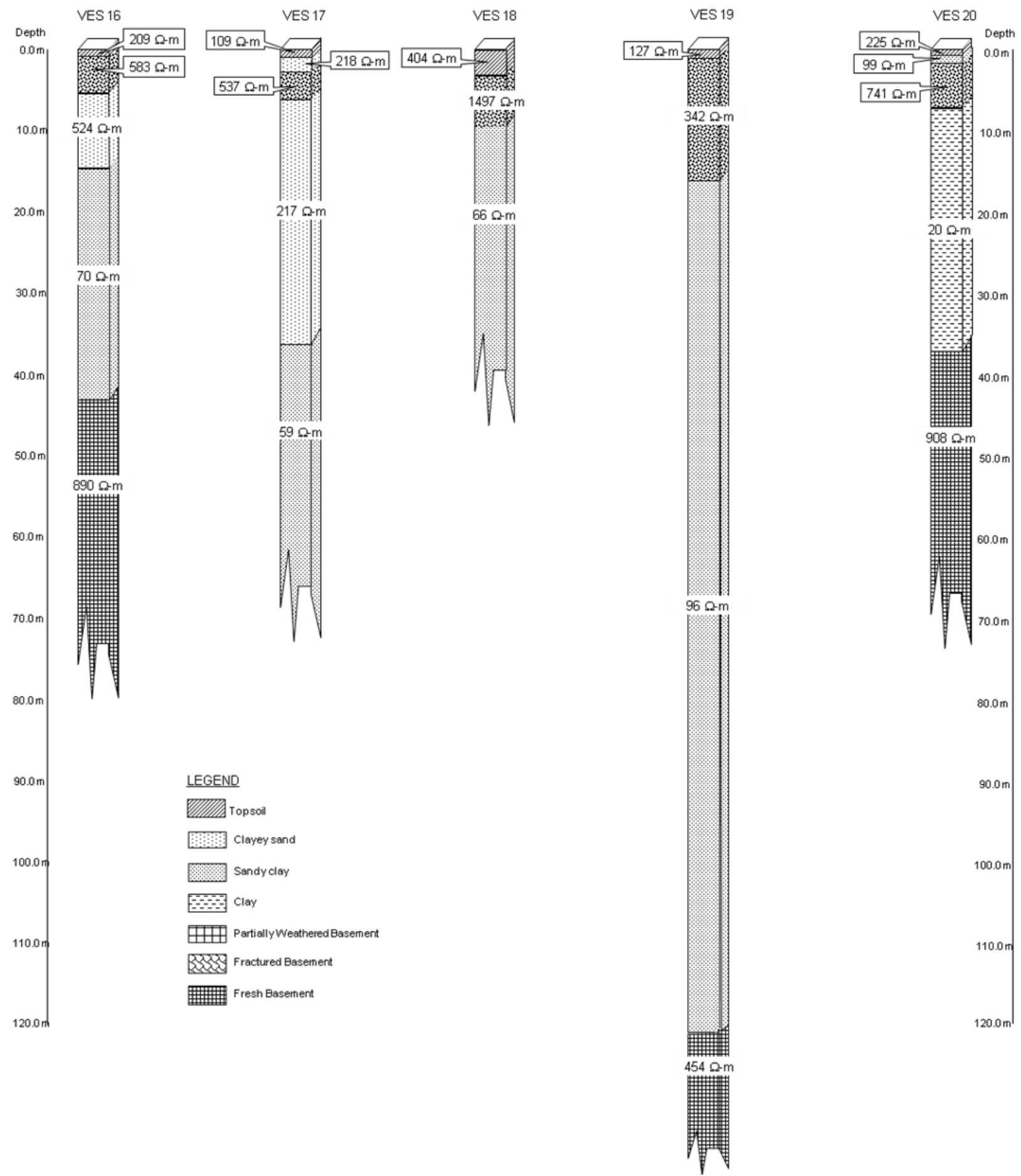

Figure 4d: 1-D Geoelectric sections of VES 16, VES 17, VES 18, VES 19 and VES 20 (Smoking Hills Golf Resort, Ilara-Mokin) 

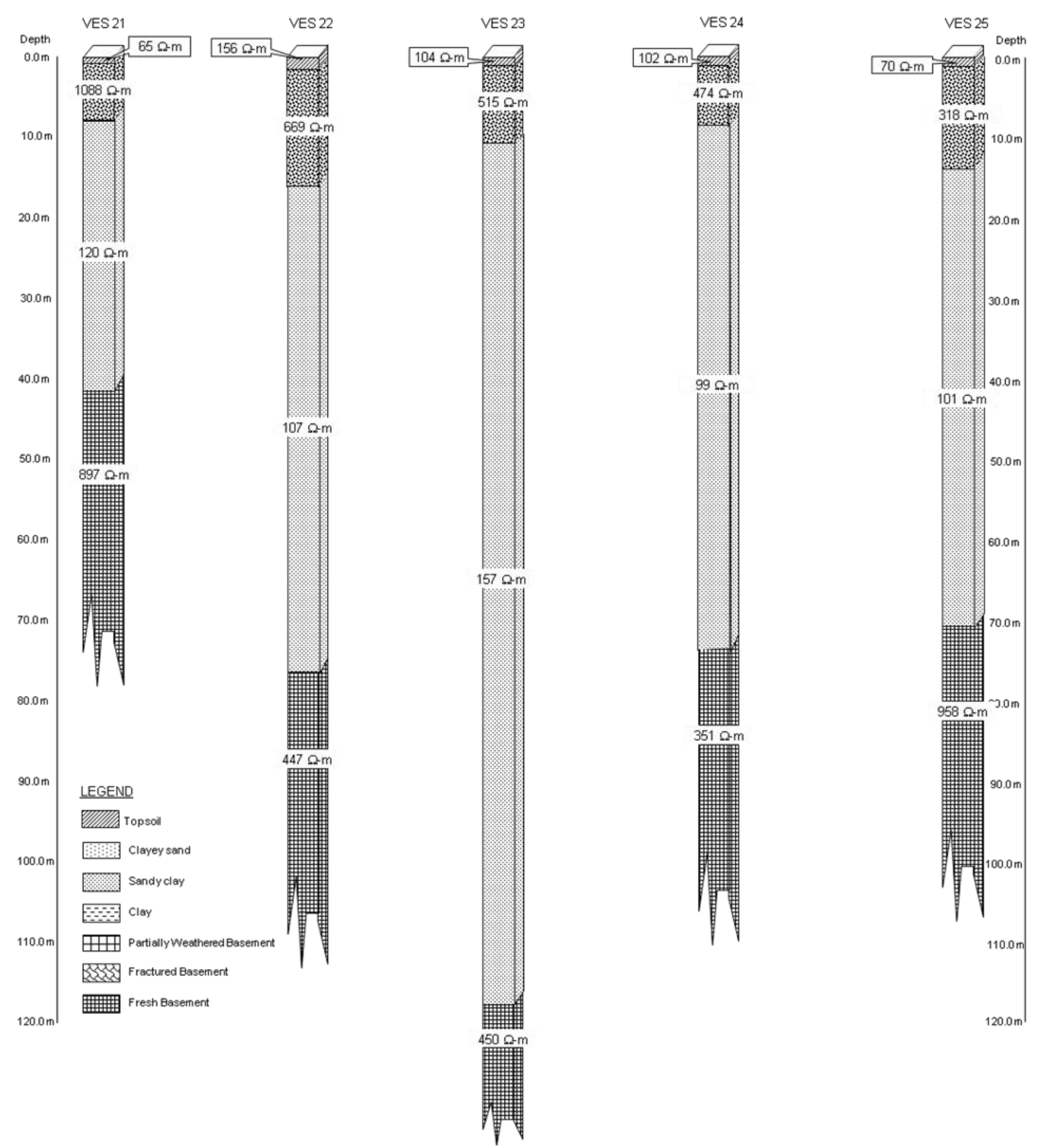

Figure 4e: 1-D Geoelectric sections of VES 21, VES 22, VES 23, VES 24 and VES 25 (Smoking Hills Golf Resort,

Ilara-Mokin)

The sounding data acquired at Smoking Hills Golf Resort in Ilara-Mokin, Ondo State presented a lithologic sequence consisting of the topsoil, thick weathered basement, partially weathered/fractured basement and the fresh bedrock.

The overburden materials within the Golf Course which are generally in excess thickness of $21.8 \mathrm{~m}$ with maximum thickness of $120.9 \mathrm{~m}$ constitute the main aquifer units with possibility of fairly adequate yield at VES 1, VES 2, VES 6, VES 8, VES 9, VES 10, VES 11, VES 12, VES 13, VES 14, VES 15, VES 16, VES 17, VES 18, VES 19, VES 20, VES 21, VES 22, VES 23, VES 24 and VES 25;

A combination of overburden materials and the partially weathered/fractured basement constitute aquifer units at with fairly adequate yield at VES 3, VES 4 and VES 7 while the partially weathered/fractured basement constitutes the main aquifer unit at VES 5.

The groundwater potential of Smoking Hills Golf Resort is of low ranking beneath only two VES locations (VES 15 and VES 20) and of medium ranking beneath the remaining twenty three (23) VES locations.

\section{CONCLUSIONS}

The groundwater potential of Smoking Hills Golf Resort is of low ranking beneath only two VES locations (VES 15 and 
VES 20) and of medium to high ranking beneath the remaining twenty three (23) VES locations;

Hydrogeologic settings beneath the Smoking Hills Golf Resort present favourable characteristics. Such favourable setting exist at VES 1, VES 2, VES 3, VES 4, VES 5, VES 6, VES 7, VES 8, VES 9, VES 10, VES 11, VES 12, VES 13, VES 14, VES 16, VES 17, VES 18, VES 19, VES 21, VES 22, VES 23, VES 24 and VES 25 and fairly favourable outlay exists beneath VES 15 and VES 20.

The poor groundwater potential underlying Ilara-Mokin town (Oladapo et al., 2009) is fairly compensated for at the Golf Course area. Thus, long term or short term groundwater development planning for Ilara-Mokin town should take cognizance of presence of favourable hydrogeologic setting in area around the Golf Course which is about $2 \mathrm{~km}$ southeast of the town.

\section{REFERENCES}

[1] Ahmed, S., Jayakumar, R. and Salih, A. (2008). Groundwater Dynamics in Hard Rock Aquifers. Springer Dordrecht. DOI: 10.1007/978-1-4020-6540-8_14

[2] Akanbi O.A. (2018). Hydrogeological Characterization and Prospect of Basement Aquifers of Ibarapa Region, Southwestern Nigeria. $\begin{array}{llll}\text { Applied Water } & \text { Science. }\end{array}$ https://doi.org/10.1007/s13201-018-0731-9

[3] Ariyo, S.O. and Adeyemi, G.O. (2009). Role of Electrical Resistivity Method for Groundwater Exploration in Hard Rock Areas: A Case Study from Fidiwo/Ajebo Areas of Southwestern Nigeria. 10(1):483-486.

[4] Barker, R., Rao, T.V. and Thangarajam, M. (2001). Delineation of contaminant zone through electrical imaging technique; Curr. Sci. 81 (3) $277-283$

[5] Badrinarayanan, T.S. (2009). Ground Water Exploration - An Introduction. B Square Geotech Services, Kollidam, Sirkalu Taluk, Nagai District, Tamilnadu. India Water Portal.

[6] Das, S.N., Mondal, N.C., and Singh V.S. (2007). Groundwater Exploration in Hard Rock Areas of Vizianagaram District, Andhra Pradesh, India . J. Ind. Geophys. Union Vol.11, No.2, pp.79-90

[7] Mondal, N.C. Das, S.N. and Singh, V.S. (2008). Integrated approach for identification of potential groundwater zones in Seethanagaram Mandal of Vizianagaram District, Andhra Pradesh, India. Journal of Earth System Science 117, No 2. pp 133-144.

[8] Oladapo, M.I., O.O. Adeoye-Oladapo and K.A. Mogaji (2009) Hydrogeophysical Study of the Groundwater Potential of Ilara-Mokin southwestern Nigeria. Global Journal of Pure and Applied Sciences Vol. 15. No 2. $195-204$.

[9] Nazri, M.A.A. (2016). Authentication Relation between Surface-Groundwater in Kerian Irrigation Canal System, Perak Using Integrated Geophysical Water Balance and Isotope Method. Procedia Engineering, 50, 284-296

[10] Riwayat, A.I., Nazri, M.A.A. and Abidin, M.H.Z. (2018). Application of Electrical Resistivity method (ERM) in Groundwater Exploration. IOP Journal of Physics: Conf. Series 995012094. DOI:10.1088/1742*6596/995/1/012094. 